\title{
Neuropsychological dimension of schizophrenia - evaluation possibilities and therapeutic implications
}

\author{
Neuropoznawczy wymiar schizofrenii - możliwości oceny oraz implikacje terapeutyczne
}

\author{
Agata Makarewicz ${ }_{\mathrm{ABDEF}}$, Hanna Karakuła- Juchnowicz ${ }^{1,2} \mathrm{AF}$, \\ Łukasz Łobejko ${ }^{1}{ }_{\mathrm{BCDEF}}$
}

${ }^{1}$ Chair and Department of Psychiatry, Psychotherapy and Early Intervention, Medical University of Lublin 2 Department of Clinical Neuropsychiatry, Medical University of Lublin

\begin{abstract}
Introduction: In the last decades, researchers' attention has been focused on cognitive dysfunction in schizophrenia. Numerous studies indicate the existence of neurodegenerative deficits in schizophrenia including, but not limited to, motor functions, learning and memory, executive functions, attention, language, spatial skills and general intelligence.

Method: A review of available literature on the topic of the past two decades, available in the Pubmed, EBSCO, SCOPUS databases has been made using the keywords: schizophrenia, cognition, early intervention.

Results: Cognitive dysfunction is an important feature of the prodromal phase and the first episode of schizophrenia. Researchers have thus proposed to initiate early therapeutic interventions for people with so-called risky mental conditions. The article includes the reference to research on neurocognitive disorders essence in schizophrenia, the definition and review of methods used to identify specific cognitive deficits and issues related to risk of developing psychosis and early therapeutic intervention in high-risk states.

Conclusions: Researchers report the importance of detecting cognitive disorders in the early stages of schizophrenia. This broadens the range of therapeutic interventions and enables early intervention in the increased risk of psychosis.
\end{abstract}

Keywords: schizophrenia, cognitive function, early intervention

\section{Streszczenie}

Wstęp: W ostatnich dziesięcioleciach uwaga badaczy kieruje się na zaburzenia funkcji poznawczych w schizofrenii. Liczne badania wskazują na istnienie deficytów neuropoznawczych w schizofrenii obejmujących $\mathrm{m}$. in. funkcje motoryczne, uczenie się i pamięć, funkcje wykonawcze, uwagę, język, umiejętności przestrzenne i ogólną inteligencję.

Metoda: Dokonano przeglądu dostępnej literatury tematu piśmiennictwa ostatnich dwóch dekad, dostępnego w bazach Pubmed, EBSCO, SCOPUS- przeszukując je za pomocą słów kluczowych: schizophrenia, cognition, early intervention

Wyniki: Dysfunkcje poznawcze stanowią ważny element obrazu fazy prodromalnej i pierwszego epizodu schizofrenii. Badacze tematu zaproponowali więc podejmowanie wczesnych interwencji terapeutycznych wobec osób z tak zwanym ryzykownym stanem psychicznym. W artykule zawarto przypomnienie badań nad istotą zaburzeń neuropoznawczych w schizofrenii, definicję oraz przegląd metod stosowanych do identyfikacji określonych deficytów poznawczych oraz zagadnienia ryzyka rozwoju psychozy i wczesnej interwencji terapeutycznej w stanach wysokiego ryzyka.

Wnioski: Doniesienia badaczy wskazują na istotną wagę detekcji zaburzeń poznawczych w początkowym okresie rozwoju schizofrenii. Poszerza to wachlarz oddziaływań terapeutycznych i umożliwia wczesną interwencję w stanach zwiększonego ryzyka rozwoju psychozy.

Słowa kluczowe: schizofrenia, funkcje poznawcze, wczesna interwencja

\section{Introduction}

Already Kreapelin found the deterioration of the cognitive functions from adolescence as characteristic feature for schizophrenia, calling it dementia praecox disease [1,2,3]. For Bleuler cognitive disorders were one of the most important axial symptoms of schizophrenia [2,4]. Cameron while investigating schizophrenia thinking disorders proposed the term "overinclusion", describing the excessive extension of the scope of concepts [2.5]. Initially, a twodimensional model of schizophrenia was assumed, which included psychopathological symptoms in two dimensions: positive and negative $[6,7,8]$, then attention was drawn to the third area of symptoms - disorganization, alongside with distortion of reality (positive dimension) 
and psychomotor deprivation (negative dimension) [9]. At the beginning of the 1990s, Kay paid attention to a group of depressive symptoms, suggesting the existence of another dimension of schizophrenia [10]. In the midnineties, Lindenmayer developed yet another fivedimensional model of schizophrenia, including the cognitive deficits identified in the group of symptoms described so far [11]. The quintessence of all current research on multidimensional models of schizophrenia is a revised American Diagnostic Criteria for Schizophrenia (DSM 5), which presents symptoms in eight dimensions of schizophrenia: hallucinations, delusions, speech disorganization, abnormal psychomotor behavior, negative symptoms, cognitive disorders, depression, and mania. [12].

The development of medical science, neurobiology, pharmacology and psychiatry has now provided more and more data on the essence of schizophrenia while addressing new research and therapeutic challenges. Recent research on cognitive deficits among people with schizophrenia suggests a link between cognitive deficits and later social functioning of patients $[13,14,15,16]$.

\section{Methods}

The available literature on the subject of the last two decades, available in the Pubmed, EBSCO, SCOPUS databases, has been reviewed, searching for: schizophrenia, cognition, early intervention.

\section{Results and discussion}

Cognitive functions are a complex set of mechanisms that allow us to discern the characteristics of the internal environment and the environment, to integrate them and to respond adequately to them [17]. Cognitive processes include areas such as attention (awareness), memory (information consolidation), knowledge integration (thinking and language processes), and finally responses to the ever-changing external world and internal stimuli. Attention is a basic cognitive process. Wciórka [17] distinguishes the following functions of attention: selectivity, durability, set-shifting, divisibility, range. Cutting [18] considers the issue of attention more globally, isolating only its two basic functions: selectivity and vigilance, and the remaining ones are treated as their derivatives. In addition, he believes that only selectivity of attention is related to cognitive processes, and vigilance is rather related to emotion-motivational processes.

Another important and fundamental cognitive element is memory. It allows for temporary and permanent preservation of information, its interpretation, use and appropriate reaction.

There are different types of memory [17]:

- ultra-short-term, iconic and echoal memory, also called sensory register, lasting $0.5-1$ seconds.
- short-term memory, lasting up to several minutes maximum, conditioned by repetition of information and circulation in neuronal circuits involving limbic structures.

- long-term, lifetime memory, for storing of which the processes of recording and coding involving the cerebral cortex are essential.

Operational memory, also called working memory, is responsible for storing, processing, monitoring and integrating information [19]. According to Cowan, operational memory is the activated part of permanent memory [20]. On the other hand, Baddeley proposed a multi-component, hierarchical model of operational memory [21].

Another division of memory distinguishes between declarative - episodic and semantic memory (so -called late) and non-declarative - procedural memory (so-called early). The declarative memory is conscious and the information contained therein is verbalizeable. Episodic memory includes situations, events and relationships between them, including temporal, emotional, and autobiographical relationships (so-called autobiographical memory). Semantic memory refers to the properties and significance of objects, knowledge about the surrounding environment. This kind of memory requires the maturity of the limbic structures of the brain and therefore does not cover the early stages of a child's life. Semantic memory occurs to some extent in mammals and birds, with the proviso that in humans it is based on the information and verbal symbols.

Episodic memory is only in humans and allows, among others, conscious perception of the future [22]. Non-declarative memory is unconscious memory, hidden, associated with the involvement of subcortical structures of the brain. It allows the storage and use of information on patterns of perceptual skills, participates in the pioneering processes, awareness-raising and habituation of memory traces. This type of memory is also associated with the processes of classical conditioning and is present from birth.

It should be emphasized that all the isolated memory processes remain in functional linkage with one another, as well as with executive functions. An example of this could be driving a car that requires complete engagement of many processes of attention and memory, from operating memory through coordinating executive functions to the use of episodic memory, long-term memory.

As demonstrated by neuroimaging methods, operational memory and executive functions are related, among others with dorsolateral prefrontal cortex activity[23]. Many neuroimaging and functional examinations of the brain confirm anomalies of the structure, blood flow and metabolism in the frontal cortex of schizophrenia patients and are currently used for schizophrenia $[24,25,26]$. Stud- 
ies in patients with schizophrenia have repeatedly pointed to impaired memory function in these patients. Currently, researchers report on memory abnormalities characterized by abnormalities in the brain network on a large scale, e.g. with abnormalities in the suppression of certain regions of the brain during cognitive involvement, i.e. underlying activity network, which may contribute to pathology of the main memory [27]. There is described a significant slowing of information processing in schizophrenia patients relative to the control group subjects $[28,29]$.

Initially, studies were reporting of general lowering of intelligence in schizophrenics. At the end of the 1990s of the twentieth century, many researchers pointed to the cognitive difficulties in patients with schizophrenia - as an "extra" dimension of schizophrenia. This happened also in view of the benefits which may flow from the early detection of cognitive deficits during pre psychotic stage and take appropriate therapeutic measures [30,31,32,33].

The researchers also propose the introduction of a new term for diseases of the schizophrenia group- schizotaxis [34]. This term describes the susceptibility or predisposition to schizophrenia and includes a large group of environmental, biological and neuropsychological factors [34,35]. According Tsuang, schizophrenia is a combination of schizotaxis with psychosis, which is the final stage of the disease. The literature also reports the broader concept of schizotaxis, to which other elements, such as perinatal complications, birth in the winter season, the older age of the father, head injuries and early childhood trauma, low intelligence, stress or psychoactive substance use are incorporated. All of these factors being a collection of traits and neurobiological and environmental conditions according to the researchers are associated with susceptibility to schizophrenia $[36,37,38]$.

Numerous studies indicate the existence of neurocognitive deficits, and they have already been unquestionably inscribed in schizophrenia $[39,40]$. These deficits include, inter alia, locomotor function, learning and memory, operational functions, attention, language, spatial ability and general intelligence. Recent studies have estimated that cognitive disorders occur in up to $90 \%$ of people with schizophrenia $[41,42,43]$; according to other researchers they are observed in $61-78 \%$ of patients [44]. Detailed studies on neurocognitive deficits in schizophrenia indicate both the lowering of general intelligence, and selective impairment of certain aspects of attention, memory, visual-spatial and language skills [45]. In particular, they relate to the processes related to information processing, problem solving, planning and abstract thinking, generally referred to as implementing processes [40]. Some studies indicate that in patients with schizophrenia, a global reduction in IQ Wechsler Scale up to 20 points occurs [46], and this applies to almost $75 \%$ of the popula- tion of patients [44]. Heinrichs and Zakzanis emphasize that among people suffering from schizophrenia, a significant minority are people without identified neuropsychological deficits. In addition, they note that in the patients who obtained the results of cognitive tests within the normal range for healthy people, there was also a reduction in their cognitive capabilities in comparison to the premorbid period [47].

Both numerous reports in the literature and clinical observations of patients with schizophrenia lead to the conclusion that cognitive impairment in most cases is preceded by the outbreak of psychosis $[48,49,50,51,52]$. Moreover, its severity in patients with the first episode of schizophrenia may be associated with the time elapsed since the onset of psychotic symptoms to undertaking of appropriate treatment [53]. This cognitive insufficiency, especially in the verbal memory, executive functions, working memory and global memory in the first psychotic episode is confirmed by data from studies of Bilder [48]. In the literature, there is also a limited number of data confirming the occurrence of cognitive deficits in children and adolescents in the early stage of the schizophrenic process. These deficits, according to different authors, are similar to those of adult patients with schizophrenia $[54,55,56,57]$.

In people with schizophrenia, cognitive difficulties largely result from abnormal processes of perception of stimuli and further processing of information. According to Graham [58] it is associated with impairment of gating process, i.e. incorrect selection of stimuli and failure in terms of the separation of significant incentives from "artifacts" or background information. These gating processes occur at the very preliminary stage of receipt of information during a few milliseconds. Graham called this process sensory-motor gating [58]. It has already been demonstrated that in patients with schizophrenia, gating processes do not function properly, and they among other factors are responsible for cognitive deficits. One of the testing methods of the efficiency of gating processes is testing of the so-called auditory evoked potentials $[59,60]$. So far, various studies have confirmed the irregularity of these processes based on the analysis of the waves P50, P200, N100, N200, P300 in patients and their healthy first-line relatives, which make them potential "candidates" to the name of endophenotypes or markers in schizophrenia [ 59,61,62]. Based on the analysis of auditory evoked potentials researchers conclude that in patients suffering from schizophrenia, there is hyper sensitivity of neurons to stimuli, and hence, reduced initial selection of information occurs [63,64]. Moreover, as demonstrated by Souza et al. [63] irregularities in the P300 wave in patients with schizophrenia correlate with the presence of neurocognitive deficits. Rassovsky's research on the technique of masking the eye also con- 
firmed abnormal processing of visual stimuli in patients with schizophrenia and their healthy relatives. Interestingly, it was shown that deficits in the processing of visual stimuli might be present in the first psychosis episode, and even during the prodromal illness. For this reason, some researchers treat visual masking disorders as an indicator of susceptibility of developing schizophrenia [65].

Many authors emphasize different aspects of the anomalies in attention process in schizophrenic patients $[51,66,67,68]$. The most frequently used research tool to assess the deficits of attention is a Continuous Performance Test (CPT). The results obtained by patients in CPT are significantly poorer to those of healthy people, and what is important, they occur in early stage of the disease $[48,66,68]$. Worse functioning of processes of attention and working memory in patients with the first episode of schizophrenia has been shown [69].

The results of recent studies on the cognitive deficits in schizophrenia are ambiguous. There is no unified position of researchers as to the severity and stability of the deficits at various stages of the disease [13,53,70,71]. Some researchers believe that certain manifestations of cognitive dysfunction, such as deterioration of attention, memory and spatial capabilities are present long before the outbreak of psychosis - about two years according to Borkowska and Rybakowski [45]. Cognitive dysfunction during this period is an important feature of the image of the prodrome phase of the disease [72,73,74]. At subsequent stages of illness, cognitive deficits may remain steady in some patients, while others progress further. Golda et al. [71] who assess overall intellectual ability among schizophrenic patients during the first episode of the disease and after 5 years of schizophrenia demonstrate that over time patients improve overall intellectual efficiency, excluding speech intelligibility.

Many researchers of cognitive functions stress that during the first five years of schizophrenia stabilizing neurocognitive deficits occur, but of course cognitive functioning remains at a level significantly lower compared with healthy controls $[71,75,76]$. The results of these studies may suggest that the first episode of the disease, followed by a cognitive stabilization is crucial for the cognitive functioning level of people suffering from schizophrenia $[13,53,71,75,77]$. In recent years, there have been conducted intensive, multi-center studies to standardize research tools for the evaluation of cognitive deficits in schizophrenia. This research has been done with the hopes of the practical use of these tools to assess neurocognitive deficits and their significance as a predictor of further functioning of patients, as well as to estimate the potential neurocognitive improvement after the application of therapeutic interventions $[78,79,80]$. The result of these research efforts was to develop within a research program MATRICS a standardized, approved by the FDA (U.S. Food and Drug administation) test battery MCCB (MATRICS Consensus Cognitive Battery). This tool used for evaluating neurodegenerative dysfunctions consists of ten tests assessing seven cognitive domains: speed processing, attention / vigilance, working memory, verbal learning, visual instruction, reasoning and problem solving, and social cognition [81].

\section{Therapeutic implications}

In order to meet today's expectations regarding the improvement of the quality of life and restoration of life activities, social and professional activities of people with schizophrenia, there are constantly sought methods for early detection of individuals at risk of developing schizophrenia and development of such therapies and rehabilitation, so that schizophrenia ceases to be a stigmatizing and exclusion disease. Researchers of the subject have proposed to make early therapeutic interventions for people with so-called risky mental state, i.e., one that predisposes to developing schizophrenia. McGorry proposed to introduce the concept of risky mental state - At Risk Mental State to identify people at high risk of developing psychosis, in whom psychosis does not meet the diagnostic criteria, included in the classification of mental disorders $[82,83]$. In turn, Yung et al. [84] proposed to make this risky mental state more clarified and introduced the status of a very high-risk - Ultra High Risk State - UHRS for people aged 19-24 years. So far, features have been identified that characterize ultra high risk of schizophrenia - UHRS, i.e. the occurrence of so-called attenuated psychotic symptoms (APS), brief limited intermittent psychotic symptoms (BLIPS) in co-occurrence with risk factors such as condition and feature (i.e. schizotypic personality disorders, having a first degree relative with psychotic disorders, significant change in mental status for at least one month, depressive symptoms, anxiety, aggression, cognitive impairment, symptoms similar to schizophrenia negative symptoms) $[85,86]$. However, there are still significant difficulties in determining the timing of transition of prepsychotic or so-called prodrome into the appropriate disease picture, while also being a great challenge for researchers $[87,88,89]$. Many authors point to the need for early pharmacological and nonpharmacological interventions in schizophrenic patients $[90,91,92]$. So far in many countries, early intervention programs and centers have been established to provide comprehensive care for people at an early stage of disease. Such early intervention programs exist in Australia, New Zealand, the United States, Canada, the United Kingdom, and Denmark. The idea of early intervention programs for schizophrenic patients includes not only early detection of disorders, but also multidisciplinary, com- 
prehensive care for patients and their families in the form of specialized pharmacological and non-pharmacological therapy: family interventions, behavioral cognitive therapy, social skills training, and problem solving, help with getting a job and extensive psycho-educational interventions for patients and their families. In 2010, Bird et al. published a meta-analysis of several large controlled studies of early intervention in different centers around the world - COAST [93], LEO [94], OPUS [95], OTP [96], in which they demonstrated that during the first five years of illness, such early and widespread interventions have the advantage over standard care. Based on the results of this meta-analysis, early intervention in schizophrenic patients is believed to result in a clinically significant reduction in the risk of relapse and re-hospitalization. This greatly increases the chances of improving the outcome of treatment and better social functioning [97].The NALPS study [98] looked for effective methods for as- sessing the risk of psychosis, allowing for early intervention and personalized treatment.

\section{Conclusions}

Cognitive impairment in schizophrenia is an important factor affecting the overall social functioning of patients. Over the years, researchers have proposed many methods for identifying neurocognitive disorders in schizophrenia. Attention of researchers often focused on gaining knowledge about the cognitive deficits seen in the first episode of schizophrenia and cognitive disorders occurring already in the prodromal stage of the disease. Detection of neurodevelopmental disorders in early schizophrenia is important for models of complex therapeutic interventions as well as for early intervention in high-risk psychosis.

\section{Wstęp}

Już Kreapelin za charakterystyczną cechę schizofrenii uznał pogarszanie się funkcji poznawczych od okresu adolescencji, nazywając chorobę dementia praecox $[1,2,3]$. Dla Bleulera zaburzenia poznawcze należały do najważniejszych, osiowych objawów schizofrenii [2,4]. Cameron badając zaburzenia myślenia w schizofrenii zaproponował termin "overinclusion", opisujący nadmierne poszerzanie zakresu pojęć [2,5]. Początkowo zakładano dwuwymiarowy model schizofrenii, ujmujący objawy psychopatologiczne w dwa wymiary: pozytywny i negatywny $[6,7,8]$, następnie zwrócono także uwagę na trzeci obszar objawówdezorganizacji, obok zniekształcenia rzeczywistości (wymiar pozytywny) i zubożenia psychomotorycznego (wymiar negatywny) [9]. Na początku lat 90-tych XX wieku Kay zwracał uwagę na grupę objawów depresyjnych, sugerując istnienie kolejnego wymiaru schizofrenii [10]. W połowie lat 90-tych Lindenmayer opracował kolejny, tym razem już pięciowymiarowy model schizofrenii, dołączając do dotychczas opisywanych grup objawów także te z kręgu zaburzeń poznawczych [11]. Kwintesencją wszystkich dotychczasowych badań nad wielowymiarowymi modelami schizofrenii jest znowelizowana, amerykańska wersja kryteriów diagnostycznych dla schizofrenii (DSM 5), ujmująca objawy w osiem wymiarów schizofrenii: halucynacje, urojenia, dezorganizację mowy, nieprawidłowe zachowania psychoruchowe, objawy negatywne, zaburzenia funkcji poznawczych, depresję i manię [12].

Rozwój nauk medycznych, neurobiologicznych, farmakologii i psychiatrii dostarcza obecnie coraz więcej danych dotyczących istoty schizofrenii, stawiając jednocześnie nowe wyzwania badawcze i terapeutyczne. Najnowsze badania nad niedomogą poznawczą wśród osób chorujących na schizofrenię sugerują związek deficytów poznawczych z późniejszym funkcjonowaniem społecznym chorych $[13,14,15,16]$.

\section{Metoda}

Dokonano przeglądu dostępnej literatury tematu piśmiennictwa ostatnich dwóch dekad, dostępnego w bazach Pubmed, EBSCO, SCOPUS- przeszukując je za pomocą słów kluczowych: schizophrenia, cognition, early intervention.

\section{Wyniki i dyskusja}

Funkcje poznawcze to skomplikowany układ mechanizmów pozwalających na rozeznanie właściwości środowiska wewnętrznego i otoczenia, scalenie ich i adekwatne reagowanie na nie [17]. Procesy poznawcze zawierają takie obszary jak: uwaga (spostrzeganie), pamięć (utrwalanie informacji), scalanie wiedzy (procesy myślenia i języka) i na końcu odpowiednie reakcje na ciągle zmieniającą się sytuację świata zewnętrznego i bodźców wewnętrznych. Uwaga jest bazowym procesem poznawczym. Wciórka [17] wyróżnia następujące funkcje uwagi: selektywność, trwałość, przerzutność, podzielność, zakres. Cutting [18] sprawę funkcji uwagi ujmuje bardziej globalnie, wyodrębniając jedynie dwie podstawowe jej funkcje: selektywność i czujność, pozostałe zaś traktuje jako ich pochodne. Ponadto uważa, że zasadniczo jedynie selektywność uwagi związana jest z procesami poznawczymi, zaś czujność jest raczej związana z procesami emocjonalno-motywacyjnymi.

Drugim ważnym i podstawowym elementem poznawczym jest pamięć. Umożliwia ona chwilowe i trwałe 
zachowanie informacji, ich interpretację, wykorzystywanie i adekwatne reagowanie.

Wyróżnia się różne rodzaje pamięci [17]:

- pamięć ultra-krótkotrwała, ikoniczna i echoiczna, nazywana też rejestrem sensorycznym, trwająca do 0.5-1 sekundy.

- pamięć krótkotrwała, trwająca do kilku, maksymalnie kilkunastu minut, uwarunkowana powtarzaniem informacji i krążeniem ich w obwodach neuronalnych z udziałem struktur limbicznych.

- pamięć długotrwała, bezterminowa, której warunkiem zmagazynowania są procesy utrwalania i kodowania przy udziale kory mózgu.

Pamięć operacyjna, zwana też roboczą jest odpowiedzialna za przechowywanie, przetwarzanie, nadzorowanie i integrację informacji [19]. Według Cowana pamięć operacyjna to zaktywizowana część pamięci trwałej [20]. Natomiast Baddeley zaproponował wielokomponentowy, hierarchiczny model pamięci operacyjnej [21].

Inny podział pamięci wyróżnia pamięć deklaratywną - epizodyczną i semantyczną(tzw. późną) i pamięć niedeklaratywną-poceduralną (tzw.wczesną). Pamięć deklaratywna jest świadoma a informacje w niej zawarte są możliwe do zwerbalizowania. Pamięć epizodyczna obejmuje sytuacje, wydarzenia i relacje między nimi, w tym także relacje czasowe, emocjonalne i autobiograficzne (tzw. pamięć autobiograficzna). Pamięć semantyczna zaś dotyczy właściwości i znaczenia obiektów, wiedzy o otaczającym środowisku. Ten rodzaj pamięci wymaga dojrzałości struktur limbicznych mózgu, dlatego też nie obejmuje wczesnych okresów życia dziecka. Pamięć semantyczna w pewnym stopniu występuje u ssaków i ptaków, z tym że u człowieka bazuje na informacjach i symbolach werbalnych. Pamięć epizodyczna jest właściwa tylko człowiekowi i pozwala m. in. na świadomą percepcję przyszłości [22]. Pamięć niedeklaratywną to pamięć nieświadoma, ukryta, związana raczej z udziałem struktur podkorowych mózgu. Umożliwia ona magazynowanie i wykorzystanie informacji dotyczących wzorców umiejętności percepcyjnych, uczestniczy w procesach torowania, uwrażliwiania i habituacji śladów pamięciowych. Ten rodzaj pamięci jest związany też z procesami klasycznego warunkowania i obecny jest od urodzenia.

Należy przy tym podkreślić, że wszystkie wyodrębnione procesy pamięciowe pozostają w połączeniu funkcjonalnym między sobą, a także $\mathrm{z}$ funkcjami wykonawczymi. Przykładem może być tu prowadzenie samochodu, które wymaga pełnego zaangażowania wielu procesów uwagi i pamięci, począwszy od pamięci operacyjnej przez koordynujące funkcje wykonawcze po wykorzystanie pamięci epizodycznej, długotrwałej.

Jak wykazały badania z użyciem metod neuroobrazowych, pamięć operacyjna i funkcje wykonawcze są związane m.in. z czynnością grzbietowo-bocznej kory przedczołowej (dorsolateral prefrontal cortex) [23]. Wiele badań neuroobrazowych i funkcjonalnych mózgu potwierdza anomalie struktury, przepływu krwi i metabolizmu w korze czołowej osób cierpiących z powodu schizofrenii i obecnie do użycia naukowego włączono pojęcie hipofrontalności w schizofrenii $[24,25,26]$. Badania u pacjentów ze schizofrenią wielokrotnie wskazywały na upośledzenie funkcjonowania pamięci operacyjnej u tych chorych. Obecnie badacze donoszą o zaburzeniach pamięci operacyjnej charakteryzujących się nieprawidłowościami w sieci mózgu na szeroką skalę - m.in. z nieprawidłowościami w tłumieniu pewnych regionów mózgu podczas kognitywnego zaangażowania, mianowicie tzw. sieci aktywności bazowej, co może przyczyniać się do patologii pamięci operacyjnej [27]. Opisywane jest istotne spowolnienie przetwarzania informacji u pacjentów chorujących na schizofrenię względem badanych z grupy kontrolnej $[28,29]$.

Początkowo badania donosiły o ogólnym obniżeniu inteligencji u osób chorych. Pod koniec lat 90-tych XX wieku wielu badaczy skierowało uwagę na trudności poznawcze u chorych na schizofrenię - jako „dodatkowy” wymiar schizofrenii. Stało się to również z myślą o korzyściach, jakie płynąć mogą z wczesnego wykrywania deficytów poznawczych w okresie prepsychotycznym i podjęcia stosownych oddziaływań leczniczych [30,31,32,33].

Badacze proponują także wprowadzenie nowego pojęcia dla chorób z grupy schizofrenii - schizotaksji [34]. Pojęcie to oznacza podatność czy pewną predyspozycję do wystąpienia zachorowania na schizofrenię i obejmuje szeroką grupę czynników środowiskowych, biologicznych i neuropsychologicznych [34,35]. Według Tsuanga schizofrenia to połączenie schizotaksji z psychozą, która stanowi ostateczny etap rozwoju choroby. W literaturze dodatkowo znaleźć można szersze pojęcie schizotaksji, do którego włączane są także inne elementy, takie jak: komplikacje okołoporodowe, urodzenie w sezonie zimowym, starszy wiek ojca, urazy głowy i traumy wczesnodziecięce, niska inteligencja, stres czy używanie substancji psychoaktywnych. Wszystkie powyższe czynniki będące zbiorem cech oraz uwarunkowań neurobiologicznych i środowiskowych według badaczy mają związek z podatnością na schizofrenię [36,37,38].

Liczne badania wskazują na istnienie deficytów neuropoznawczych i zostały one już $\mathrm{w}$ niekwestionowany sposób wpisane w schizofrenię [39,40]. Deficyty te obejmują m. in. funkcje motoryczne, uczenie się i pamięć, funkcje wykonawcze, uwagę, język, umiejętności przestrzenne i ogólną inteligencję. Dotychczasowe badania oceniają, że zaburzenia procesów poznawczych występują nawet u $90 \%$ osób chorych na schizofrenię $[41,42,43]$; według innych badaczy są obserwowane u $61-78 \%$ cho- 
rych [44]. Bardziej szczegółowe badania nad deficytami neuropoznawczymi w schizofrenii wskazują zarówno na osłabienie inteligencji ogólnej, jak i wybiórcze upośledzenie niektórych aspektów uwagi, pamięci, funkcji wzrokowo-przestrzennych czy zdolności językowych [45]. W szczególności zaś dotyczą procesów związanych $\mathrm{z}$ przetwarzaniem informacji, rozwiązywaniem problemów, planowaniem i myśleniem abstrakcyjnym, określanych ogólnie jako procesy wykonawcze [40]. Niektóre badania wskazują, że u osób chorych na schizofrenię następuje globalne obniżenie Ilorazu Inteligencji w Skali Wechslera nawet o 20 punktów [46], a dotyczy to prawie $75 \%$ populacji osób chorych [44]. Heinrichs i Zakzanis podkreślają, że wśród osób cierpiących z powodu schizofrenii w znaczącej mniejszości znajdują się osoby bez stwierdzonych deficytów neuropsychologicznych. Ponadto zauważają oni, że u osób chorych, które uzyskiwały wyniki w testach poznawczych w granicach normy dla osób zdrowych, również doszło do obniżenia ich możliwości kognitywnych w porównaniu z okresem przedchorobowym [47].

Zarówno liczne doniesienia w literaturze, jak i obserwacje kliniczne osób chorych na schizofrenię pozwalają na stwierdzenie, że zaburzenia funkcji poznawczych w większości przypadków wyprzedzają wybuch psychozy [48,49,50,51,52] a ich nasilenie u osób z pierwszym epizodem schizofrenii może być związane z czasem, jaki upłynął od wystąpienia pierwszych objawów psychotycznych do podjęcia stosownego leczenia [53]. Tę niedomogę poznawczą, szczególnie w zakresie pamięci słownej, funkcji wykonawczych, pamięci operacyjnej i pamięci globalnej już w pierwszym epizodzie psychotycznym potwierdzają dane $\mathrm{z}$ badań Bildera [48]. W literaturze istnieje także ograniczona liczba danych potwierdzających występowanie deficytów poznawczych u dzieci i młodzieży we wczesnym etapie procesu schizofrenicznego. Deficyty te według różnych autorów są zbliżone do tych stwierdzanych u osób dorosłych chorych na schizofrenię [54,55,56,57].

U osób chorych na schizofrenię trudności poznawcze w dużej mierze wynikają z nieprawidłowych procesów percepcji bodźców i dalszego przetwarzania informacji. Według Grahama [58] jest to związane z zaburzeniami procesów bramkowania, czyli nieprawidłowej selekcji bodźców i niedomogą w zakresie oddzielania bodźców istotnych od „artefaktów” czy tła informacyjnego. Te procesy bramkowania zachodzą na bardzo wstępnym etapie odbioru informacji, w czasie kilku milisekund. Graham nazwał ten proces bramkowaniem sensorycznomotorycznym [58]. Dowiedziono już, że u osób chorych na schizofrenię procesy bramkowania nie funkcjonują w sposób prawidłowy i to one między innymi czynnikami odpowiadają za deficyty poznawcze. Jednym ze sposobów badania sprawności procesów bramkowania jest badanie tzw. słuchowych potencjałów wywołanych [59,60].
Dotychczas wiele badań potwierdziło nieprawidłowości tych procesów na podstawie analizy załamków P50, P200, N100, N200, P300 u osób chorych oraz ich zdrowych krewnych pierwszego stopnia, co sprawia, że są to potencjalni „kandydaci” do miana endofenotypów czy też markerów w schizofrenii $[59,61,62]$. Na podstawie analizy słuchowych potencjałów wywołanych badacze stwierdzają, że u osób cierpiących z powodu schizofrenii ma miejsce hiperwrażliwość neuronów na bodźce, a co za tym idzie, następuje obniżona wstępna selekcja informacji [63,64]. Ponadto, co wykazali Souza i wsp. [63] nieprawidłowości w zakresie załamka P300 u osób chorych na schizofrenię korelują z obecnością deficytów neuropoznawczych. Badania Rassovskyiego nad techniką maskowania wzrokowego potwierdzają także zaburzenia procesów przetwarzania bodźców wzrokowych u osób chorych na schizofrenię oraz ich zdrowych krewnych. Co ciekawe, wykazano przy tym, że deficyty przetwarzania bodźców wzrokowych występować mogą już w pierwszym epizodzie psychozy, a nawet $\mathrm{w}$ okresie prodromalnym choroby. $\mathrm{Z}$ tego też powodu niektórzy badacze traktują zaburzenia maskowania wzrokowego jako wskaźnik podatności zachorowania na schizofrenię [65].

Wielu autorów podkreśla różne aspekty nieprawidłowości procesów uwagi u chorych na schizofrenię $[51,66,67,68]$. Najczęściej stosowanym narzędziem badawczym do oceny deficytów uwagi jest Test Ciągłego Wykonywania (CPT - Continuous Performance Test). Wyniki uzyskiwane przez osoby chore w CPT są znacząco gorsze od wyników osób zdrowych, a co ważne, występują one już we wczesnej fazie choroby $[48,66,68]$. Wykazano bowiem gorsze funkcjonowanie procesów uwagi i pamięci operacyjnej u chorych z pierwszym epizodem schizofrenii [69].

Wyniki dotychczasowych badań nad deficytami poznawczymi w schizofrenii są niejednoznaczne. Nie ma bowiem jednolitego stanowiska badaczy co do nasilenia i stabilności tych deficytów na różnych etapach choroby $[13,53,70,71]$. Niektórzy badacze uważają, że pewne przejawy dysfunkcji poznawczych, takie jak pogorszenie uwagi, pamięci operacyjnej czy funkcji przestrzennych, są obecne na długo przed wybuchem psychozy - około dwóch lat według Borkowskiej i Rybakowskiego [45]. Dysfunkcje poznawcze $\mathrm{w}$ tym okresie stanowią ważny element obrazu fazy prodromalnej choroby [72,73,74]. Na dalszych etapach choroby deficyty poznawcze mogą utrzymywać się na stałym poziomie u niektórych chorych, u innych zaś wykazują dalszą progresję [45]. Badania Golda i wsp. [71] oceniające ogólną sprawność intelektualną wśród chorych na schizofrenię w trakcie pierwszego epizodu choroby i po 5 latach trwania leczonej schizofrenii wykazują, że u chorych $\mathrm{z}$ biegiem czasu następuje poprawa ogólnej sprawności intelektualnej, z wyłącze- 
niem inteligencji słownej. Wielu badaczy funkcji poznawczych podkreśla, że w ciągu pierwszych pięciu lat trwania schizofrenii dochodzi do stabilizacji deficytów neuropoznawczych, choć oczywiście funkcjonowanie poznawcze pozostaje na poziomie znacząco niższym w porównaniu z osobami zdrowymi $[71,75,76]$. Wyniki tych badań mogą sugerować, że kluczowe znaczenie dla poziomu funkcjonowania poznawczego osób cierpiących z powodu schizofrenii ma pierwszy epizod choroby, po czym następuje pewna stabilizacja poznawcza $[13,53,71,75,77]$.

W ostatnich latach trwały intensywne, wieloośrodkowe badania w celu standaryzacji narzędzi badawczych służących do oceny deficytów poznawczych w schizofrenii. Poszukiwania te czyniono z nadziejami praktycznego wykorzystania tych narzędzi do oceny deficytów neuropoznawczych i ich znaczenia jako predyktora dalszego funkcjonowania chorych, a także do szacowania ewentualnej poprawy neuropoznawczej po zastosowaniu oddziaływań terapeutycznych $[78,79,80]$. Efektem tych poszukiwań badawczych było opracowanie w ramach programu badawczego MATRICS standaryzowanej, zaakceptowanej przez FDA (U.S. Food and Drug Administation) baterii testowej MCCB (MATRICS Consensus Cognitive Battery). To narzędzie służące do oceny dysfunkcji neuropoznawczych składa się z dziesięciu testów oceniających siedem domen poznawczych: szybkość przetwarzania (speed processing), uwagę/czujność, pamięć roboczą, uczenie słowne, uczenie wzrokowe, rozumowanie i rozwiązywanie problemów oraz poznanie społeczne [81].

\section{Implikacje terapeutyczne}

Wychodząc naprzeciw współczesnym oczekiwaniom dotyczących podnoszenia jakości życia oraz przywrócenia aktywności życiowej, społecznej i zawodowej osób cierpiących na schizofrenię, nieustannie trwają poszukiwania metod wczesnej detekcji osób z grupy ryzyka zachorowania na schizofrenię oraz wypracowania takich metod terapeutycznych i rehabilitacyjnych, które sprawią, że schizofrenia przestanie być chorobą stygmatyzującą i wykluczającą. Badacze tematu zaproponowali więc podejmowanie wczesnych interwencji terapeutycznych wobec osób z tak zwanym ryzykownym stanem psychicznym, tzn. takim, który predysponuje do zachorowania na schizofrenię. McGorry zaproponował wprowadzenie pojęcia ryzykownego stanu psychicznego - At Risk Mental State dla identyfikacji osób z wysokim ryzykiem rozwoju psychozy, u których psychoza nie spełnia jednak kryteriów diagnostycznych ujętych w klasyfikacjach chorób psychicznych [82,83]. Z kolei Yung i wsp. [84] zaproponowali, aby ten ryzykowny stan psychiczny bardziej uściślić i wprowadzili określenie stanu bardzo wysokiego ryzyka - Ultra High Risk State - UHRS dla osób w wieku 19-24 lat. Dotychczas zidentyfikowano cechy charaktery- czynnikiem mającym wpływ na całokształt funkcjonowania zujące stan bardzo wysokiego ryzyka zachorowania na schizofrenię - UHRS, tj. występowanie tzw. atenuowanych, zwiewnych objawów psychotycznych (APS - attenuated psychotic symptoms), krótkotrwałych, przelotnych objawów psychotycznych (BLIPS - brief limited intermittent psychotic symptoms) we współwystępowaniu z czynnikami ryzyka typu stan i cecha (tj. schizotypowe zaburzenia osobowości, posiadanie krewnego pierwszego stopnia z zaburzeniami psychotycznymi, znacząca zmiana stanu psychicznego przez minimum jeden miesiąc, objawy depresyjne, lękowe, agresja, zaburzenia funkcji poznawczych, objawy podobne do objawów negatywnych schizofrenii) $[85,86]$. Istnieją jednak nadal znaczne trudności w określeniu momentu przejścia stanu prepsychotycznego czy tzw. prodromalnego we właściwy obraz chorobowy, stanowiąc równocześnie wielkie wyzwanie dla badaczy $[87,88,89]$.

Wielu autorów zwraca uwagę na konieczność wczesnych interwencji farmakologicznych i pozafarmakologicznych u osób chorych na schizofrenię $[90,91,92]$. Dotychczas w wielu krajach stworzono programy i ośrodki wczesnej interwencji, zajmujące się kompleksową opieką nad osobami w początkowym etapie choroby. Takie programy wczesnej interwencji funkcjonują między innymi w Australii, Nowej Zelandii, Stanach Zjednoczonych, Kanadzie, Wielkiej Brytanii, Danii. Idea programów wczesnej interwencji dla osób chorych na schizofrenię obejmuje nie tylko wczesną detekcję zaburzeń, ale także wielodyscyplinarną, kompleksową opiekę nad chorymi i ich rodzinami pod postacią specjalistycznej terapii farmakologicznej i pozafarmakologicznej: interwencje rodzinne, terapię behawioralno-poznawczą, treningi umiejętności społecznych i skutecznego rozwiązywania problemów, pomoc w podjęciu pracy, a także szerokie oddziaływania psychoedukacyjne dla pacjentów i ich rodzin. W 2010 r. Bird i wsp. opublikowali wyniki metaanalizy kilku dużych kontrolowanych badań na temat wczesnych interwencji w różnych ośrodkach na świecie - badania: COAST [93], LEO [94], OPUS [95], OTP [96], w której wykazali, że w okresie pierwszych pięciu lat trwania choroby takie wczesne i szerokie interwencje mają przewagę nad opieką standardową. Na podstawie wyników tej metaanalizy uważa się, że wczesna, kompleksowa interwencja u osób chorych na schizofrenię skutkuje istotną klinicznie redukcją ryzyka nawrotu choroby i ponownych hospitalizacji. Tym samym znacznie zwiększa szansę na poprawę wyników leczenia osób chorych oraz lepsze ich funkcjonowanie społeczne [97]. Badanie NALPS [98] poszukiwało skutecznych metod oceny ryzyka rozwoju psychozy, umożliwiających wczesną interwencję i spersonalizowane leczenie.

\section{Wnioski}

Zaburzenia poznawcze w schizofrenii są istotnym 
społecznego osób chorych. Na przestrzeni lat badacze zaproponowali wiele metod identyfikacji zaburzeń neuropoznawczych w przebiegu schizofrenii. Uwaga badaczy często skupiała się na zdobyciu wiedzy o deficytach poznawczych widocznych $\mathrm{w}$ pierwszym epizodzie schizofrenii oraz na zaburzeniach poznawczych występujących już w prodromalnym okresie choroby. Detekcja zaburzeń neuropoznawczych we wczesnym okresie rozwoju schizofrenii jest istotna dla modeli kompleksowych oddziaływań terapeutycznych jak i dla metod wczesnej interwencji w stanach zwiększonego ryzyka psychozy.

\section{Conflict of interest}

The authors have declared no conflict of interest.

\section{References:}

1. 1.Kraepelin, E., 1971. Dementia praecox and paraphrenia. Robert E. Krieger Publishing Co. Inc., Huntington, NY.

2. Green M.F., Harvey P.D. Cognition in schizophrenia: Past, present and future. Schizophrenia Research: Cognition 1(2014) e1-e9.

3. Kahn R.S. Dlaczego Kraepelin miał rację: schizofrenia jako zaburzenie poznawcze. Neuropsychiatria i Neuropsychologia 2014; 9 , 2: 41-47

4. Bleuler, E., 1950. Dementia praecox or the group of schizophrenias. International Universities Press, New York, N.Y.

5. Cameron, N., 1939. Schizophenic thinking in a problem-solving situation. Br. J. Psychiatry 85, 1012-1035.

6. Andreasen N.C., Olsen S. Negative versus positive schizophrenia. Definition and validation.Arch. Gen. Psychiatry. 1982; 39(7): 789-794.

7. Crow T.J. Positive and negative schizophrenic symptoms and the role of dopamine. Br. J. Psychiatry. 1980; 137: 383-386.

8. Crow T.J. The two-syndrome concept: origins and current status. Schizophr. Bull. 1985; 11(3): 471-486.

9. Liddle P.F. The symptoms of chronic schizophrenia. A reexamination of the positive--negative dichotomy. Br. J. Psychiatry. 1987; 151: 145-151.

10. Kay S.R. Positive-negative symptom assessment in schizophrenia: psychometric issues and scale comparison. Psychiatr. Q. 1990; 61(3): 163-178.

11. Lindenmayer J.P., Grochowski S., Hyman R.B. Five factor model of schizophrenia: replication across samples. Schizophr. Res. 1995; 14(3): 229-234.

12. APA. DSM-5 Development. 2012; http:www.dsm5.org. (pobrano: 2013-05-10).

13. Green M.F., Kern R.S., Heaton R.K. Longitudinal studies of cognition and functional outcome in schizopfrenia: implications for MATRICS. Schizophr. Res. 2004; 70: 117-145.

14. Green M.F., Schooler N.R., Kern R.D. Evaluation of functionallymeaningful measures for clinical trials of cognition enhancement in schizophrenia. Am. J. Psychiatry. 2011; 168: 400-407.

15. Leung W.W., Bowie C.R., Harvey P.D. Functional implications of neuropsychological normality and symptom remission in older outpatiens diagnosed with schizophrenia: a cross-sectional study. I. Int. Neuropsychol. Soc. 2008; 14: 479-488.

16. Rosenheck R., Leslie D., Keefe R. Barriers to employement for people with schizophrenia. Am. J. Psychiatry. 2006; 163: 411-417.
17. Wciórka J. Psychiatria t. I, Bilikiewicz A., Pużyński S., Rybakowski J., Wciórka J. (red.) Wyd. Urban\&Parnter, Wrocław 2002; 333-340.

18. Cutting J. Principles of psychopatology; two worlds - two minds two hemispheres. Oxford Univ. Press, Oxford 1997.

19. Strelau J. , Doliński D. Psychologia. Podręcznik akademicki. GWP, Gdańsk 2008, t. 2; 429-431.

20. Cowan N. An embedded-processes model of working memory. Models of working memory: Mechanisms of active maintenance and executive control. 1999, Vol. 20; 506

21. Baddeley A., Wilson BA. Prose recall and amnesia: implications for the structure of working memory. Neuropsychologia 2002; 40(10): 1737-43

22. Borkowska A. Neuropsychologiczne i neurobiologiczne aspekty pamięci operacyjnej. Neuropsychiatria i Neuropsychologia. 2006; 1(1): 31-42.

23. Walter H., Wunderlich A.P., Blankenhorn M., Schäfer S., Tomczak R., Spitzer M., Grön G. No hypofrontality, but absence of prefrontal lateralization comparing verbal and spatial working memory in schizophrenia. Schizophr. Res. 2003; 61(2): 175-184.

24. Carter C.S., Perlstein W., Ganguli R., Brar J., Mintun M., Cohen J.D. Fuctional hypofrontality and working memory dysfunction inschizophrenia. Am. J. Psychiatry. 1998; 155(9): 1285-1287.

25. Goldman-Rakic P.S., Muly E.C., Williams G.V. D1 receptors in prefrontal cells and circuits. Brain Res. Rev. 2000; 31: 295-301.

26. Webster M.J., Weickert C.S., Herman M.W., Kleinman J.E. BDNF mRNA expression during postnatal development, maturation and aging of the human prefrontal cortex. Brain Res. Dev. 2002; 139: 139-150.

27. Pawęzka J., Karakuła-Juchnowicz H., Welcz H. Neuroobrazowanie zaburzeń pamięci operacyjnej w schizofrenii: od teorii hipofrontalności do zaburzeń sieci aktywności bazowej. Curr. Probl. Psychiatry, 2014; 15(4):176-183.

28. Ojeda N., Pena J., Schretlen DJ, Sanchez P., Aretouli E., Elizagarate J., Ezcurra J., Gutierrez M. Hierarchical structure of the cognitive processes in schizophrenia: the fundamental role of processing speed. Schizophr Res. 2012 Mar;135(1-3):72-8.

29. Rodriguez-Sanchez JM, Ayesa-Arriola R., Perez-Iglesias R., Perianez JA, Martinez-Garcia O., Gomez-Ruiz E.,TabaresSeisdedos R., Crespo-Facorro B. Course of cognitive deficits in first episode of non-affective psychosis: a 3-year follow-up study. Schizophr Res. 2013 Oct;150(1):121-8.

30. Bowie C.R., Leung W.W., Reichenberg A., McClure M.M. Predicting schizophrenia patients' real-world behavior with specific neuropsychological and functional capacity measures. Biol. Psychiatry. 2008; 63: 505-511.

31. Carpenter W.T. Anticipating DSM V: should psychosis risk become a diagnostic class? Schizophr. Bull. 2009; 35: 841-843.

32. Heckers $\mathrm{S}$. Who is at risk for a psychotic disorder? Schizophr. Bull. 2009; 35: 847-850.

33. Rabe-Jabłońska J., Kotlicka-Antczak M. (red.) Ryzykowny stan psychiczny, Wyd. Termedia, Poznań 2012; 19-34.

34. Tsuang M.T., Stone W.S., Faraone S.V. Understanding predisposition to schizophrenia: toward intervention and prevention. Can. J. Psychiatry. 2002b; 47(6): 518-526.

35. Tsuang M.T., Faraone S.V. Diagnostic concepts and prevention of schizophrenia. Can. J. Psychiatry. 2002a; 47(6): 515-517.

36. Fogelson D.L., Nuechterlein K.H., Asarnov R.F., Payne D.L., Subotnik K.L. Validity of the family history method for diagnosisng schizophrenia, schizophrenia-related psychoses, and schizophrenia-spectrum personality dosorders in first-degree relatives of schizophrenia probands. Schizophr. Res. 2004; 68(1-2): 309-317.

37. Krysta K., Krupka-Matuszczyk I., Janas-Kozik M., Stachowicz M., Szymszal J., Rybakowski J. Inferior performance on selected neuropsychologic tests in abstinent schizophrenia patients who have used cannabis. Med. Sci. Manit. 2012; 18(9): 581-586. 
38. Lawrie S.M., Olabi B., Hall J., McIntosh A.M. Do we have any evidence of clinical utility about the pathophysiology of schizophrenia? World Psychiatry. 2010; 10: 19-31.

39. Harvey P.D., Starssing M. Predicting the severity of everyday functional disability in people with schizophrenia: cognitive deficits, functional capacity, symptoms and health status. World Psychiatry. 2012; 11(2): 73-79.

40. Kurtz M.M., Tolman A. Neurocognition, insight into illness and subjective quality of life in schizophrenia: what is their relationship? Schizophr. Res. 2011; 127(1-3): 157-162.

41. Borkowska A. Dysfunkcje poznawcze w schizofrenii w ocenie neuropsychologicznej i neurofizjologicznej. Akademia Medyczna w Bydgoszczy, Bydgoszcz 2002.

42. Borkowska A. Zaburzenia funkcji poznawczych w schizofrenii. (w:) Bilikiewicz A., Pużyński S., Rybakowski J., Wciórka J. (red.) Psychiatria t. I. Urban \& Partner, Wrocław 2002; 545-548.

43. Waldo M.C., Carrey G., Myles-Worsley M. Codistribustion of a sensory gating in schizophrenic patients and their relatives. Psychiatry Res. 1991; 39: 257-268.

44. Lewis R. Should cognitive deficit be a diagnostic criterion for schizophrenia? J. Psychiatry Neurosci. 2004; 29(2): 102-113.

45. Borkowska A., Rybakowski J. Deficyty poznawcze w schizofrenii. (w:) Borkowska A. (red.) Zaburzenia funkcji poznawczych w chorobach psychicznych. Biblioteka Psychiatrii Polskiej, Kraków 2005; 7-23.

46. Borkowska A. Lateralizacja dysfunkcji psychicznych w schizofrenii w świetle wybranych badań neuropsychologicznych. Praca doktorska. Akademia Medyczna w Bydgoszczy, Bydgoszcz 1996.

47. Heinrichs R.W., Zakzanis K.K. Neurocognitive deficit in schizophrenia: a quantative review of the evidence. Neuropsychology. 1998; 12(3): 426-445.

48. Bilder R.M., Reiter G., Bates J., Lencz T., Szeszko P., Goldman R.S. Robinson D., Lieberman J.A., Kane JM. Cognitive development in schizophrenia: follow-back from the first episode. J. Clin. Experim. Neuropsychology. 2006; 28(2): 270-282.

49. Byrne M., Hodges A., Grant E., Owens D.C., Johnstone E.C. Neuropsychological assessement of young people at high genetic risk for developing schizophrenia compared with controls: preliminary findings of the Edinburgh High Risk Study (EHRS). Psychol. Med. 1999: 29(5): 1161-1173.

50. Cannon T.D., Bearden C.E., Hollister J.M., Rosso I.M., Sanches L.E., Headley T. Childhood cognitive functioning in schizophrenia patients and their unaffected siblings: a prospective cohort study. Schizophr. Bull. 2000a; 26(2): 379-393.

51. Cornblatt B.A., Keilp J.G. Impaired attention, genetics, and the pathophysiology of schizophrenia. Schizophr. Bull. 1994; 20(1): 31-46.

52. Seidman L.J., Giuliano A.J., Meyer E.C., Addington J., Cadenhead K.S., Cannon T.D., McGlashan T.H., Perkins D.O., Tsuang M.T., Walker E.F., Woods S.W., Bearden C.E., Christensen B.K., Hawkins K., Heaton R., Keefe R.S.E., Heinssen R., Cornblatt B.A. Neuropsychology of the prodrome to psychosis in the NAPLS consortium: relationship to family history and conversion to psychosis. Arch. Gen. Psychiatry. 2010; 67(6): 578-588.

53. Meltzer H.Y. Cognitive factors in schizophrenia: causes, impact and treatment. CNS Spectr. 2004; 9: 15-24.

54. Asarnov R.F., Asamen J., Granholm E., Sherman T., Watkins J.M., Williams M.E. Cognitive/neuropsychological studies of children with a schizophrenic disorder. Schizophr. Bull. 1994; 20(4): 647669.

55. Banaschewski T. Schultz E., Martin M., Remschmidt H. Cognitive functions and psychopathological symptoms in early-onset schizophrenia. Eur. Child Adolesc. Psychiatry. 2000; 9(1): 11-20.
56. Øie M., Rund B.R. Neuropsychological deficits in adolescent-onset schizophrenia compared with attention deficit hyperactivity disorder. Am. J. Psychiatry. 1999; 15(8): 1216-1222.

57. Woodberry K.A., Giuliano A.J., Seidman L.J. Premorbid IQ in schizophrenia: a meta--analytic review. Am. J. Psychiatry. 2008; 165(5): 579-587.

58. Graham F.K. The more or less startling effects of weak prestimulation. Psychophysiology. 1975; 12: 238-248.

59. Light G.A., Swerdlow N.L., Rissling A.J., Radant A., Sugar C.A., Sprock J., Pela M., Geyer M.A., Braff D.L. Characterization of neuropsychologic and neurocognitive biomarkers for use in genomic and clinical outcome studies of schizophrenia. PLoS One. 2012; 7(7): e39434

60. Rissling A.J., Makeig S., Braff D.L., Light G.A. Neurophysiologic markers of abnormal brain activity in schizophrenia. Curr. Psychiatry Rep. 2010; 12(6): 572-578.

61. Karakuła H. Poszukiwanie wskaźników genetycznej podatności na schizofrenię. Rozprawa habilitacyjna. Akademia Medyczna, Lublin 2007.

62. Lin Y.T., Liu C.M., Chiu M.J., Liu C.C., Chien Y.L., Hwang T.J., Jaw F.S., Shan J.C., Hsieh M.H., Hwu H.G. Differentiation of schizophrenia patients from healthy subjects by mismatch negativity and neuropsychological tests. PLoS One. 2012; 7(4): e34454.

63. Souza V., Muir W., Walker M., Glabus M., Roxborough H., Sharp C., Dunan J., Blackwood D. Auditory P300 event-realted potentials and neuropsychological performance in schizophrenia and bipolar affective disorders. Boil. Psychiatry. 1995; 37: 300-310.

64. Wynn J.K., Dawson M.E., Schell A.M., McGee M., Salveson D., Green M.F. Prepulse facilitation and prepulse inhibition in schizophrenia patients and their unaffected siblings. Biol. Psychiatry. 2004; 55: 518-523.

65. Rassovsky Y., Green M.F., Nuechterlein K.H., Breitmeyer B., Mintz J. Paracontrast and metacontrast in schizophrenia: claryfing the mechanism of visual masking deficits. Schizophr. Res. 2004; 71: 485-492.

66. Bilder R.M., Lipschultz-Broch L., Reiter G., Geisler S.H., Mayerhoff D.I., Lieberman J.A. Intellectual deficits in the first-episode schizophrenia: evidence for progressive deterioration. Schizophr. Bull. 1992; 18: 437-448.

67. Frangou S., Hadjulis M., Vourdas A. The Maudsley Early Onset Schizophrenia Study: cognitive function over a 4-year follow-up study. Schizophr. Bull. 2008; 34(1): 52-59.

68. Saykin A.J., Shtasel D.L., Gur R.E., Kester D.B., Mozley L.H., Stafiniak P., Gur R.C. Neuropsychological deficits in neuroleptic naïve patients with first-episode schizophrenia. Arch. Gen. Psychiatry. 1994; 51: 124-131.

69. Cornblatt B.A., Malhotra A.K. Impaired attention as an ednophenotype for molecular genetic studies of schizophrenia. Am. J. Med. Gen. 2001; 105: 11-15.

70. Addington J., Saedi H., Addington D. The course of cognitive functioning in the first episode psychosis: changes over time and impact on outcome. Schizophr. Res. 2005; 78: 35-43

71. Gold S., Arndt S., Nopoulos P., O'Leary D., Andreasen N. Longitudinal study of cognitive function in first-episode and recent-onset schizophrenia. Am. J. Psychiatry. 1999; 156: 1342-1348.

72. Bowie C.R., McLaughlin D., Carrion R.E., Auther A.M., Cornblatt B.A. Cognitive changes following antidepressant or antipsychotic treatment in adolescents at clinical risk for psychosis. Schizphr. Res. 2012; 137(1-3): 110-117.

73. Brewer W.J., Wood S.J., Philips L.J., Francey S.M., Pantelis C., Yung A.R., Cornblatt B., McGorry P.D. Generalized and specific cognitive performance in clinical high cohorts: a review highlighting potential vulnerability markers for psychosis. Schizophr. Bull. 2006; 32(3): 538-555.

74. Harvey P.D. When does cognitive decline occur in the period to the first episode of schizophrenia? Psychiatry (Edgmont). 2009; 6: 12-14. 
75. Hoff A.L., Svetina C., Shields G., Steward J., DeLisi L.E. Ten year longitudinal study of neuropsychological functioning subsequent to a first episode of schizophrenia. Schizophr. Res. 2005; 78: 27-34.

76. Kurtz M.M. Neurocognitive impairment across the lifespan in schizophrenia: an update. Schizophr. Res. 2005; 74: 15-26.

77. Stirling J., White C., Lewis S., Hopkins R., Tantam D., Huddy A., Montague L. Neurocognitive function and outcome in the firstepisode schizophrenia: a 10-year follow--up of an epidemiological cohort. Schizophr. Res. 2003; 65(2-3): 75-86.

78. Keefe R.S., Buchanan R.W., Marder S.R., Schooler N.R., Dugar A., Zivkov M., Stewart M. Clinical trials of potential cognitiveenhancing drugs in schizophrenia: what have we learned so far? Schizophr. Bull. 2011; 39(2): 417-435.

79. Marder S.R. Lessons from MATRICS. Schizophr. Bull. 2011; 37(2): 233-234.

80. Shamsi S., Lau A., Lencz T., Burdick K.E., DeRosse P., Brebber R., Lindenmayer J.P., Malhotra A.K. Cognitive and symptomatic predictors of functional disability in schizophrenia. Schizophr. Res. 2011; 126(1-3): 257-264.

81. Kern R., Neuchterlein K., Green M., Baade L., Fenton W., Gold J., Keefe R., Meshoalm-Gateley R., Mintz J., Seidman L., Stover E., Marder S. The MATRICS cognitive battery, part 2-co norming and standardization. Am. J. Psychiatry 2008; 165: 214-220.

82. McGorry P.D., Edwards J., Mihalopoulos C., Harrigan S., Jackson H.J. EPPIC: an envolving system of early detection and optimal management. Schizophr. Bull. 1996; 22: 305-326.

83. McGorry P.D., Killackey E., Yung A. Early intervention in psychosis:concepts, evidence and future directions. World Psychiatry. 2008; 7(3): 148-156.

84. Yung A.R., Philips L.J., Nelson B., Francey S.M., PanYuen H., Simmons M.B., Ross M.L., Kelly D., Baker K., Amminger G.P., Berger G., Thompson A.D., Thampi A., McGorry P.D. Randomised controlled trial of interventions for young people at ultra high risk for psychosis: a 6month analysis. J. Clin. Psychiatry. 2011; 72(4): 430-440.

85. Cornblatt B.A., ObuchowskiM. Roberts S., Pollack S., ErlenmeyerKimliong L. Cognitive and behavioral precursors of schizophrenia. Dev. Psychopathol. 1999; 11(3): 487-508.

86. Yung A.R., McGorry P.D. The initial prodrome in psychosis: descriptive and qualitative aspects. Aust. N. Z. J. Psychiatry. 1996; 30: 587-599.

87. Rabe-Jabłońska J., Kotlicka-Antczak M., Gmitrowicz A. Obraz kliniczny i czas trwania objawów zwiastunowych w schizofrenii u młodzieży. Psychiatria Pol. 1999; 33(5): 715-725.

88. Szulc A., Czernikiewicz A. Stany prepsychotyczne - współczesne koncepcje diagnostyczne i terapeutyczne. Część II. Markery biologiczne ryzyka rozwoju schizofrenii. Terapia stanów prepsychotycznych. Psychiatria Pol. 2007; 1: 17-21.

89. van Os J., Hanssen M., De Graff I., Vollebergh W. Does the urban environment independently increase the risk for both negative and positive features of psychosis? Soc. Psychiatry Psychiatr. Epidemiol. 2002; 37(10): 460-464.
90. Birchwood M., Fowler D., Jackson C. (eds.) Early intervention in psychosis: guide to concepts, evidence and intervention. Wiley, Chichester City, UK 2000.

91. Bottlender R., Sato T., Jager M. The impact of the duration of untreated psychosis prior to first psychiatric admission on the 15-year outcome in schizophrenia. Schizophr. Res. 2009; 62: 37-44.

92. Joseph. R., Birchwood M. The national policy reforms for mental health services and the story of early intervention services in the United Kingdom. J.Psychiatry Neurosci. 2005; 30: 362-365.

93. Kuipers E., Holloway F., Rabe-Hesketh S., Tennakoon L. An RCT of early intervention in psychosis: Ceaydon Outreach and Assertive Support Team (COAST). Soc. Psychiatr. Epidemiol. 2004; 39: 359-363.

94. Craig T., Garety P., Power P., Rahaman N., Colbert S., FornellsAmbroyo M., Dunn G. The Lambeth Early Onset Team: randomized, controlled trial of the effectiveness of specialized care for early psychosis. Br. M. Journal. 2004; 329: 1067-1071.

95. Petersen L., Jeppesen P., Thorup A., Abel M.B., Øhlenschlaeger J., Christensen T.Ø., Krarup G., Jørgensen P., Nordentoft M. A randomized, multicentre trial of integrated versus standard treatment for patients with a first episode of psychotic illness. Br. M. Journal. 2005; 331: 602-608.

96. Grawe R.W., Falloon I.R., Widen J.H., Skogvoll E. Two years of continued early treatment for recent-onset schizophrenia: a randomized controlled study. Acta Psychiatr. Scand. 2006; 114: 328-336.

97. Bird V., Premkumar T., Kendall C., Whittington J., Mitchel J., Kuipers E. Early intervention services, cognitive-behavioural therapy and family intervention in early psychosis: systemic review. Br. J. Psychiatry. 2010; 197: 350-356.

98. Carrión R.E., Cornblatt B.A., Burton C.Z., Tso I.F., Auther A.M., Adelsheim S., Calkins R., Carter C.S., Niendam T., Sale T.G., Taylor S.F., McFarlane W.R. Personalized Prediction of Psychosis: External Validation of the NAPLS-2 Psychosis Risk Calculator With the EDIPPP Project. American Journal of Psychiatry. Volume 173, Issue 10 , October 01,2016 , pp. $989-996$

\section{Correspondence address}

Agata Makarewicz

Katedra i I Klinika Psychiatrii, Psychoterapii i Wczesnej Interwencji

20-439 Lublin, ul. Głuska 1

tel. 817487307

Otrzymano: 10.11.2016

Zrecenzowano: 13.12.2016

Przyjęto do druku: 16.01.2017 